\title{
DISCURSO PRONUNCIADO POR EL PRESIDENTE DEL COLEGIO DE ABOGADOS DE LA REGIÓN DE COQUIMBO, DON MANUEL CORTÉS BARRIENTOS, EN EL CEMENTERIO INGLÉS DE COQUIMBO, CON MOTIVO DE LAS EXEQUIAS DEL ABOGADO DON HUGO ZEPEDA BARRIOS
}

\section{SEÑORAS Y SEÑORES:}

El Colegio de Abogados de la Cuarta Región de Coquimbo, despide en este campo santo a don Hugo Zepeda Barrios, su más antiguo colegiado, uno de los más preclaros exponentes del Abogado en el ámbito político nacional , y a uno de sus más dignos y probos integrantes.

Don Hugo Zepeda Barrios, el joven que vino de las tierras del interior de la antigua provincia de Coquimbo, desde ese corazón verde del Limarí, que estudiara en el Liceo de Ovalle y en la Universidad de Chile, obtuvo su título de abogado e ingresó al Colegio de Abogados, el 13 de noviembre de 1928.

Su ejercicio profesional en el foro, estuvo en este puerto de Coquimbo, pero la actividad del servicio público, marcó su impronta vital desde 1932 cuando fuera elegido Diputado, en una tarea política que culminara como Presidente del Senado, en la década de los 60 .

Queremos destacar al despedir los restos mortales de nuestro llustre Colega, la figura del Abogado entregado al servicio del bien común actuando en la Política, que es también uno de los roles que nuestra profesión lleva a cabo en el medio social.

"Cuando los pueblos viven épocas de conquista o de defensa armada es natural que en ella predominan los guerreros; cuando no atraviesan tales etapas excepcionales sino tiempos de paz y de progreso, necesariamente han de buscar fórmulas jurídicas para vivir, $y$ al afecto requerirán a quienes tengan capacidad para proporcionárselas. Esto no es trazar la política; esto es, modestamente servirla con los elementos de la competencia técnica". (Ossorio)

Esa fue la tarea asumida por el Abogado Zepeda Barrios, el que abogaba viendo los grandes fenómenos sociales en los casos concretos, el que viendo lo social reflejado en lo individual busca la guía adecuada inspirada en aquello, teniendo como norte, el amor a la patria, a la tierra ancestral, y al respeto de la dignidad del hombre.

En los días que corren, las expresiones maledicentes equívocas y deshonestas acerca de conductas y actuaciones, presumidas de deshonrosas o ilícitas, dedicadas a los abogados, como paradigmas nocivos de todos los vicios, cruzan los ámbitos de la Justicia la Política y el Foro. 
Revista de Derecho - Universidad Católica del Norte - Sede Coquimbo - 1998

No caben en este mara magnum de la vindicta pública, a los abogados en general, las conductas probas, honestas y dignas de los más.

Somos todos medidos con un rasero que lleva en sí, el estigma y la reprobación, que sólo debería perseguir a aquellos que efectivamente han violado el deber jurídico y la norma ética que se conjura en nuestra profesión.

Frente a estos hechos, una vida como la de este Hombre que fuera Abogado, por casi 70 años, don Hugo Zepeda Barrios, constituyen un ejemplo digno de ser imitado.

Pero a la vez son una incitación y una clara demostración a nuestra sociedad, que es posible corregir lo necesario, desarrollar lo perfectible y generar lo nuevo en aras de la Justicia, básicamente a través que los Abogados en el campo del foro y ejercicio liberal de la profesión, en lo político, lo judicial, en las asesorías o servicio público, y en cualquier campo, asumamos la tarea ineludible da nuestro perfeccionamiento profesional, y de nuestra dignificación ética.

Don Hugo Zepeda Barrios, el 30 de noviembre de 1995, en el Palacio Arzobispal de La serena, entre la Catedral y la Corte, fue objeto de nuestro homenaje, y en aquella ocasión nos dijo que, "OBRAR CON RECTITUD Y DILIGENCIA EN LAS LABORES JURIDICAS, NOS HARA HONRAR NUESTRA PROFESION".

Su vida y su conducta son un paradigma y sus palabras, un mensaje que no debemos olvidar. 